\title{
Defining and Measuring Interpersonal Continuity of Care
}

\author{
Jobn W. Saultz, MD \\ Department of Family Medicine, School \\ of Medicine, Oregon Health \& Science \\ University, Portland, Ore
}

\begin{abstract}
BACKGROUND In an effort to learn more about the importance of continuity of care to physicians and patients, I reviewed the medical literature on continuity of care to define interpersonal continuity and describe how it has been measured and studied.

METHODS A search of the MEDLINE database from 1966 through April 2002 was conducted to find articles focusing on the keyword "continuity of patient care," including all subheadings. Titles and abstracts of the resulting articles were screened to select articles focusing on interpersonal continuity in the physicianpatient relationship or on the definition of continuity of care. These articles were systematically reviewed and analyzed for study method, measurement technique, and research theme.

RESULTS A total of 379 original articles were found that addressed any aspect of continuity as an attribute of general medical care. One hundred forty-two articles directly related to the definition of continuity or to the concept of interpersonal continuity in the physician-patient relationship. Although the available literature reflects little agreement on how to define continuity of care, it is best defined as a hierarchy of 3 dimensions; informational, longitudinal, and interpersonal continuity. Interpersonal continuity is of particular interest for primary care. Twenty-one measurement techniques have been defined to study continuity, many of which relate to visit patterns and concentration rather than the interpersonal nature of the continuity relationship.
\end{abstract}

CONCLUSIONS Future inquiry in family medicine should focus on better understanding the interpersonal dimension of continuity of care.

Ann Fam Med 2003;1:134-143. DOI: 10:1370/afm.23.

\section{INTRODUCTION}

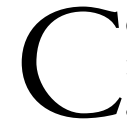

ontinuity of care is considered to be a defining characteristic of family practice and has been defined by the Institute of Medicine as a core attribute of primary care. ${ }^{1}$ Even before the birth of family practice as a specialty, continuity of care was mentioned in the 3 influential reports of 1966 - the Folsom Report, Millis Report, and Willard Report - as a need to be addressed by the new field. ${ }^{2}$ For family physicians, continuity implies a longitudinal relationship between patients and those who care for them that transcends multiple illness episodes and includes responsibility for preventive care and care coordination..$^{2,3}$ In the ideal case, this longitudinal relationship evolves into a strong bond between physician and patient characterized by trust, loyalty, and a sense of responsibility.

Changes in American health care during the past 2 decades have undermined the ability of patients to choose and remain with an individual physician. ${ }^{4}$ Health plans sometimes change physician panels, which might require patients to change physicians from year to year. ${ }^{4-6}$ Medical groups have become larger and have organized into networks, so that call 
arrangements and clinic schedules make personal relationships between individual physicians and patients more difficult than ever to establish and maintain. ${ }^{7,8}$ As these changes have occurred, there has been disagreement but little informed debate about what might be lost as care becomes more technical and efficient, but less intimate and personal. ${ }^{9-12}$ What proof is there that a continuous longitudinal relationship improves the quality of health care? What aspects of continuity matter most to physicians and patients?

To learn more about the importance of continuity of care to physicians and patients, a comprehensive literature review was conducted to examine evidence regarding the value of continuity as a characteristic of physician-patient relationships. From the outset, this review was complicated by the lack of consensus regarding how to define and measure continuity. For example, many studies in the nursing literature have studied how information should be transmitted from one nursing shift to another or from hospital nurses to nursing home nurses. Other references address continuity of outpatient medical or psychiatric follow-up after hospital discharge without regard to who actually provides this follow-up. These articles tend to define continuity of care as the availability of clinical information to any provider who cares for the patient. The goal of this review was to examine continuity as a characteristic of the relationship between physician and patient, a concept that may be called interpersonal continuity. Thus, this review was limited to 2 types of articles: those written to define the concept of continuity, and those that address interpersonal continuity in the physician-patient relationship as a characteristic of health care delivery. The purposes of this article are to describe how continuity has been defined and how various investigators have tried to measure interpersonal continuity. A new conceptual definition of continuity is proposed based on this review. Future articles will outline evidence regarding the benefits of interpersonal continuity and will describe what remains to be learned as a research agenda for primary care and health policy researchers.

\section{METHODS}

A search of the medical literature from January 1, 1966, to April 30, 2002, was undertaken using the MEDLINE database. A subject search of "continuity of care" generated the medical subject heading "continuity of patient care." The search was limited to articles focusing on this subject heading, including all possible subheadings. This search produced 2,424 citations in the English language. The titles and reference citations of each of these articles were reviewed, and references were eliminated if it they were letters to the editor, if they addressed health professions other than medicine, or if they addressed only aspects of continuity other than interpersonal continuity. Most of these eliminated references focused on communication of information among various health professionals in various settings. Many of the more recent references have focused on the development of comprehensive health information systems in managed care settings. Excluding these articles left 379 citations that appeared to address continuity as an attribute of the relationship between providers and patients in general medical care. I obtained and read full-text copies of each of these articles. In addition, I scanned the bibliographies of each article to find references that were missed by the MEDLINE search.

Following this process, I found 142 articles that directly related to the concept of interpersonal continuity. Forty-one were review articles or theory articles dealing with continuity of care in general. The remaining 101 were original research reports. All of the citations were entered into a bibliographic database. I then classified each by study method, primary research question(s), and measurement technique, and this information was recorded in the database for each article. Study method and measurement techniques were determined by reading the methods section of each article and either recording the method cited by the authors or assigning the method based on its description by the authors. Reading the introduction of each article and recording the author's stated purpose of the study determined the primary research questions. The database could then be sorted in turn by research question(s), study methodology, and measurement technique.

\section{RESULTS}

\section{Fundamental Themes About Continuity of Care}

Listing the specific research questions for each reference in the database allowed the questions to be grouped into the 13 categories listed in Table 1 based on the theme(s) of the articles. After the themes were determined, the reference database was updated with information about the theme of each reference, thereby allowing the articles to be sorted in this way. Table 1 also lists the references addressing each broad theme. Some references address more than one theme. To clarify the difference between the concept of broad themes and the specific research questions addressed by each article, Table 2 lists the 17 references that relate to a theme regarding the measurement of continuity of care. The remainder of this article will focus on themes 1 and 2, definition and measurement. Future articles will address the other themes. 


\begin{tabular}{|c|c|c|c|}
\hline No. & Research Theme & $\begin{array}{l}\text { Papers } \\
\text { Reviewed } \\
\text { No. }\end{array}$ & Reference Citations \\
\hline 1 & $\begin{array}{l}\text { What is the best conceptual definition } \\
\text { of continuity? }\end{array}$ & 17 & $10,13-28$ \\
\hline 2 & $\begin{array}{l}\text { What is the best way to measure } \\
\text { continuity of care? }\end{array}$ & 17 & $13,14,20-22,29-40$ \\
\hline 3 & $\begin{array}{l}\text { Are patients who receive interpersonal } \\
\text { continuity more satisfied with their care? }\end{array}$ & 31 & $12,14,16,33,41-67$ \\
\hline 4 & $\begin{array}{l}\text { What patient characteristics correlate } \\
\text { with choosing an interpersonal } \\
\text { continuity model? }\end{array}$ & 20 & $\begin{array}{l}36,44,46,48,49,51,52 \\
58,62,68-78\end{array}$ \\
\hline 5 & $\begin{array}{l}\text { Is health care better in any measurable } \\
\text { way when delivered in interpersonal } \\
\text { continuity? }\end{array}$ & 54 & $\begin{array}{l}5,6,13,14,17,25,35,36, \\
42,45,53-56,60,61,64, \\
66-68,74,79-110\end{array}$ \\
\hline 6 & $\begin{array}{l}\text { Are physicians more satisfied with } \\
\text { practice when an interpersonal } \\
\text { continuity model is followed? }\end{array}$ & 12 & $\begin{array}{l}14,16,42,52,53,55,61 \\
62,67,111-113\end{array}$ \\
\hline 7 & $\begin{array}{l}\text { Is health care less expensive when } \\
\text { delivered in interpersonal continuity? }\end{array}$ & 20 & $\begin{array}{l}42,53,54,57,61,66,80 \\
72,84,88,90-92,108 \\
114-119\end{array}$ \\
\hline 8 & $\begin{array}{l}\text { Can interpersonal continuity be } \\
\text { improved by organizing a practice in } \\
\text { a particular way? }\end{array}$ & 22 & $\begin{array}{r}12,17,33,46,52-55,59 \\
63,69,76,94,120-128\end{array}$ \\
\hline 9 & $\begin{array}{l}\text { Why do patients leave the care of a } \\
\text { physician with whom they have } \\
\text { interpersonal continuity? }\end{array}$ & 13 & $\begin{array}{l}4-6,58,69,71,73,126 \\
129-133\end{array}$ \\
\hline 10 & $\begin{array}{l}\text { What do primary care physicians value } \\
\text { regarding continuity of care? }\end{array}$ & 21 & $\begin{array}{l}10,13,16,17,23,26,27 \\
33,52,61,62,77,85 \\
112,122,134-139\end{array}$ \\
\hline 11 & $\begin{array}{l}\text { What do patients value regarding } \\
\text { continuity of care? }\end{array}$ & 18 & $\begin{array}{c}16,17,33,44,46,49,51 \\
52,59,60,62,65,69 \\
70,104,131,136,140\end{array}$ \\
\hline 12 & $\begin{array}{l}\text { Does geographic continuity matter to } \\
\text { patients? }\end{array}$ & 10 & $\begin{array}{l}28,41,70,79,80,135 \\
\quad 141-144\end{array}$ \\
\hline 13 & $\begin{array}{l}\text { How are changes in the health care } \\
\text { system affecting continuity? }\end{array}$ & 16 & $\begin{array}{c}4-6,9-12,61,76,114,120 \\
133,141,142,144,145\end{array}$ \\
\hline
\end{tabular}

ical history does not imply any relationship with that patient.

Chronologic or longitudinal continuity of care refers to an ongoing pattern of health care interaction that occurs in the same place, with the same medical record, and with the same professionals, so that there is a growing knowledge of the patient by those providing the care. Longitudinal continuity implies a pattern of visits but does not directly address the nature of the relationship between patient and provider. Interpersonal continuity refers to a special type of longitudinal continuity in which an ongoing personal relationship between the patient and care provider is characterized by personal trust and responsibility.

Geograpbic continuity relates to care that is provided with continuity regardless of the location of the patient (office, home, hospital, etc). The volume of literature addressing this type of continuity has increased considerably during the past 5 years as hospitalist programs have developed in many large hospitals. ${ }^{41,79,80,141-144}$ Interdisciplinary or team-based continuity, also referred to as the continuity

\section{Theme 1: What Is the Best Conceptual Definition of Continuity?}

There is little uniformity in how continuity of care has been defined by different authors. Several authors defined multiple dimensions of continuity. ${ }^{2,13-22}$ Among these dimensions are informational continuity, ${ }_{1}^{13,14,21}$ chronologic or longitudinal continuity, ${ }_{1}^{2,13-24}$ interpersonal continuity, ${ }^{1,13-18,19,21.23-27}$ geographic continuity, ${ }^{2,14,19,21}$ interdisciplinary or team-based continuity, ${ }^{2,10,14,19,21}$ and family continuity. ${ }^{2,29}$ Informational continuity implies that each provider caring for a patient has access to comprehensive information about the patient's previous health care encounters even if different providers in different locations provide the care. There is a huge volume of medical literature about this issue, most of which was systematically excluded from this review. A common methodologic problem in continuity research is confusion about the difference between knowledge of the patient and a relationship with the patient. One can know about a patient by reading a medical history, but knowing a patient's med- of generalism, implies care that allows previous knowledge of the patient to be present even when the patient requires a wide range of services spanning the traditional medical specialties. ${ }^{2}$ Family continuity is defined as a system of care in which all family members receive care from providers who have ongoing knowledge of the health problems of other family members. ${ }^{2,29}$

McWhinney describes interpersonal continuity as the essential concept for primary care. ${ }^{24}$ He defines continuity of care as an implicit contract between physician and patient in which the physician assumes ongoing responsibility for the patient, and states: "The key word here is responsibility. Obviously the physician cannot be available at all times, nor can he or she carry out all the care a patient may need. The doctor is responsible for ensuring continuity of service by a competent deputy and for following through when some aspect of care is delegated to a consultant." Loxterkamp ${ }^{28}$ refers to this same sense of responsibility in stating that the essence of continuity is "being there" 
Table 2. References Addressing Theme 2: What Is the Best Way to Measure Continuity of Care?

\begin{tabular}{ll}
\hline Reference & Primary Research Question \\
Bice \& Boxerman, 197730 & How can continuity of care best be measured? \\
Ejlertsson \& Berg, 198434 & How do the quantitative measures of continuity compare with \\
one another?
\end{tabular}

Longitudinal continuity creates a familiar setting in which care can occur and should make it easier for patients to access care when needed, but it does not assure a relationship of personal trust between an individual physician and patient. Many articles in the primary care literature have addressed the concept of interpersonal continuity, but several different measurement methods have been used, and few conclusions are applicable to health care in general.

By arranging these concepts as a hierarchy, it is implied that at least some informational continuity is required for longitudinal continuity to be present and that longitudinal continuity is required for interpersonal continuity to exist in a physician-patient relationship. This hierarchy does not include the concepts of geographic, interdisciplinary, or family con-

when the patient needs us. In contrast, Rogers and Curtis ${ }^{21}$ state, "continuity is present in a medical encounter when at least one participating element has previous knowledge of the other." This definition focuses on information rather than characteristics of the interpersonal relationship, as suggested by McWhinney. A careful reading of the references in this review reflects no consensus about how to define continuity of care, even though this methodologic problem has been discussed for more than 20 years. In the absence of an agreed-upon vocabulary about continuity, it becomes difficult to generalize findings from one study with another, which is particularly surprising given the philosophical importance of continuity to the primary care medical disciplines.

From these various definitions, it appears that continuity can best be defined as a hierarchical concept ranging from the basic availability of information about the patient's past to a complex interpersonal relationship between physician and patient characterized by trust and a sense of responsibility. Table 3 places these concepts in a hierarchy of increasing complexity and represents a synthesis of these concepts. At the base of this hierarchy is the notion of informational continuity. This concept might be the most important aspect of continuity in preventing medical errors and insuring patient safety, but by itself informational continuity might not improve access to or satisfaction with care. tinuity, which can be considered aspects of 1 or more of the 3 basic concepts.

If we define continuity as a hierarchy, then several important researchable questions come into focus. Consider the following examples of such questions: To what extent does a pattern of longitudinal continuity add to the availability of informational continuity about the patient? In an era of electronic medical records and integrated health systems, can enough information be recorded in the electronic record to allow patients to seek care in many different sites without loss of information? What is the relationship between longitudinal continuity and the development of interpersonal continuity? How many times does a patient need to see a physician before the relationship takes hold? If a strong interpersonal continuity relationship exists between physician and patient, for how long and under what circumstances will the relationship tolerate a visit pattern without longitudinal continuity? None of these questions can be addressed if we are not clear about which variable is being considered and measured. Many of the most important questions about continuity of care actually deal with the relationship among these parameters.

\section{Theme 2: How Can Continuity of Care Be Measured?}

Although many of the articles included in this review used a measurement tool to quantify continuity, 17 


\section{Table 3. Hierarchical Definition of Continuity of Care}

$\begin{aligned} & \text { Level of } \\ & \text { Continuity }\end{aligned}$
$\begin{aligned} & \text { 1. Informational } \\ & \text { An organized collection of medical and social information about each } \\ & \text { patient is readily available to any health care professional caring for } \\ & \text { the patient. A systemic process also allows accessing and communicating } \\ & \text { about this information among those involved in the care }\end{aligned}$
$\begin{aligned} & \text { 2. Longitudinal } \\ & \text { addition to informational continuity, each patient has a "medical home" } \\ & \text { occur in an accessible and familiar environment from an organized } \\ & \text { team of providers. This team assumes responsibility for coordinating the } \\ & \text { quality of care, including preventive services } \\ & \text { In addition to longitudinal continuity, an ongoing relationship exists } \\ & \text { between each patient and a personal physician. The patient knows the } \\ & \text { physician by name and has come to trust the physician on a personal } \\ & \text { basis. The patient uses this physician for basic health services and } \\ & \text { depends on the physician to assume personal responsibility for the } \\ & \text { patient's overall health care. When the personal physician is not available, } \\ & \text { a coverage arrangement assures that longitudinal continuity occurs }\end{aligned}$

satisfaction. ${ }^{12,14,16,33,41-67}$ Some of these studies included aspects of the physician-patient relationship, such as duration, loyalty, and trust as part of the assessment of satisfaction, but the focus of these articles was on satisfaction rather than the strength of the relationship. Only 7 studies specifically compared visit patterns to any aspect of patient loyalty or trust. ${ }^{46,52,54,56,60,64,66}$ Could it be that a patient might have a strong personal identification with one provider characterized by loyalty and trust, but still see several different providers during the period being examined by a particular study? Is this not what

articles discussed or reviewed the advantages of various measurement techniques (Table 2). ${ }^{13,14,20-22,29-40}$ Several approaches have been used in designing these instruments. Some have been based on visit patterns only, whereas others have required an individual provider to be defined as the "usual" or "primary" provider for each patient. For example, formulas that measure the concentration of visits with various providers, such as the Continuity of Care Index, ${ }^{30}$ do not require a registry that assigns a physician for each patient. These indices simply measure the number of providers seen and reflect a higher continuity score when there are larger numbers of visits with a smaller number of providers. In contrast, other measures, such as the Usual Provider Continuity Index, ${ }^{120}$ have been designed to quantify how visit patterns relate to the patient's assignment to a usual provider.

Some authors have distinguished between visit-based measures and individual-based measures. ${ }^{14,20,32,38,39}$ Doing so has presented a common methodologic problem in designing continuity studies, because many medical offices do not have functional and accurate patient assignment data systems. Some investigators have attempted to overcome this problem by arbitrarily assigning either the first provider seen ${ }^{35,81,114}$ or the most frequently seen provider ${ }^{121}$ as the usual provider. This method might work for studies examining longitudinal care patterns, but these measures might not tell us anything about the nature of the physician-patient relationship. In fact, many of these studies are measuring longitudinal continuity even though they are trying to make inferences about interpersonal continuity.

No studies found in this review were specifically designed to compare visit patterns with the strength of interpersonal continuity, but 31 studies examined the relationship between continuity of care and patient happens when a physician goes on vacation or is absent because of illness?

Table 4 lists various indices that have been created to measure continuity of care and the studies addressing interpersonal continuity that have used each measurement technique. Some of the measurement techniques listed in Table 4 have never been used in any of the studies reviewed in this article. These instruments might have been used in research addressing other aspects of continuity. The mathematical formulas for these instruments can be found in several review articles and texts on this subject. 2,22,37-40

The measurement tools in Table 4 are separated into 3 groups. The first 12 instruments listed in the table do not require a primary physician to be determined $_{i}$ instead, they examine patterns of visits. Instruments in the second group require a specific individual as the primary provider, although some make this assignment arbitrarily based on visit pattern. For example, the Most Frequent Provider Continuity Index (MFPC) ${ }^{40,121}$ defines the primary provider as the one seen most frequently during the study period, and the Index Provider Identification ${ }^{35}$ process defines the first provider seen as the primary provider. Also included in this second group are simple surveys regarding continuity. Some studies have simply asked patients whether they have a usual provider or to report the duration of their relationship with this provider. Others have administered questionnaires to have patients rate their perceptions of continuity.

Measurement instruments in the third group were designed to measure family continuity, a concept that should be important for family medicine. Each of these 3 tools, however, is simply an adaptation of one of the individual measures that examine visit patterns. None of the family continuity instruments were used as a tool 


\begin{tabular}{|c|c|c|c|}
\hline Instruments & $\begin{array}{l}\text { Interpersonal Continuity } \\
\text { References Using } \\
\text { This Measure }\end{array}$ & Instruments & $\begin{array}{l}\text { Interpersonal Continuity } \\
\text { References Using } \\
\text { This Measure }\end{array}$ \\
\hline \multicolumn{2}{|l|}{$\begin{array}{l}\text { Measures that do not } \\
\text { require an assigned provider }\end{array}$} & \multicolumn{2}{|l|}{$\begin{array}{l}\text { Measures that require } \\
\text { an assigned provider }\end{array}$} \\
\hline $\begin{array}{l}\text { Continuity of Care Index } \\
\text { (COC) })^{30-32,34,36-40}\end{array}$ & $\begin{array}{l}\text { Christakis et al, } 2000^{110} \\
\text { Christakis et al, } 1999^{118} \\
\text { Flynn, } 1985^{45} \\
\text { Roos et al, } 1980^{36} \\
\text { Sloane \& Eglehoff, } 1983^{75} \\
\text { Wasson et al, 198466 }\end{array}$ & Duration of relationship ${ }^{14}$ & $\begin{array}{l}\text { Hjortdahl, 199283 } \\
\text { Hjortdahl \& Laerum, 199247 } \\
\text { Love \& Mainous, } 1999^{69} \\
\text { Mainous et al, 200160 } \\
\text { Overland et al, 200168 } \\
\text { Weiss \& Bluestein, 199684 }\end{array}$ \\
\hline \multirow{3}{*}{$\begin{array}{l}\text { Number of Providers Seen } \\
(\text { NOP) })^{20} \\
\text { Sequential Continuity Index } \\
(\text { SECON) })^{20,34,37,38,40}\end{array}$} & $\begin{array}{l}\text { Raddish et al, } 1999^{117} \\
\text { Shortell et al, } 1977^{49}\end{array}$ & \\
\hline & $\begin{array}{l}\text { Shortell et al, } 1977^{49} \\
\text { Phillips \& Shear, } 1984^{88}\end{array}$ & $\begin{array}{l}\text { Most Frequent Provider } \\
\text { Continuity (MFPC) }\end{array}$ & Merenstein et al, $2001^{121}$ \\
\hline & $\begin{array}{l}\text { Pilotto et al, } 1996^{73} \\
\text { Shear et al, } 1983^{64} \\
\text { Wasson et al, } 1984^{66}\end{array}$ & Index Provider Identification ${ }^{35}$ & $\begin{array}{l}\text { Meredith et al, } 2001^{114} \\
\text { Starfield et al, } 1976^{35} \\
\text { Susman et al, } 1989^{81}\end{array}$ \\
\hline $\begin{array}{l}\text { Likelihood of Continuity } \\
\text { Index (LICON) }\end{array}$ & & \multirow{5}{*}{$\begin{array}{l}\text { Patient survey, interview, or } \\
\text { questionnaire }\end{array}$} & Wasson et al, $1984^{66}$ \\
\hline $\begin{array}{l}\text { Index (LICON) } \\
\text { Likelihood of Sequential } \\
\text { Continuity Index } \\
\text { (LISECON) }^{20,38}\end{array}$ & & & $\begin{array}{l}\text { Breslau, 198251 } \\
\text { Breslau \& Mortimer, } 1981^{44} \\
\text { Ettlinger \& Freeman, } 1981^{87} \\
\text { Ettner, 1996109 }\end{array}$ \\
\hline Herfindahl Index $(\mathrm{HH})^{20,39}$ & & & Ettner, $1999^{97}$ \\
\hline $\begin{array}{l}\text { Modified Continuity Index } \\
(\mathrm{MCl})^{31,37}\end{array}$ & $\begin{array}{l}\text { Gill \& Mainous, } 1998^{90} \\
\text { Gill et al, 2000115 } \\
\text { Neher et al, 2001 } \\
\text { Sturmberg \& Schattner, 2001100 }\end{array}$ & & $\begin{array}{l}\text { Hanninen et al, } 2001^{101} \\
\text { Hennelly \& Boxerman, } 19799^{92} \\
\text { Hjortdahl \& Borchgrevink, } 1991^{116} \\
\text { Hjortdahl \& Laerum, 1992 }\end{array}$ \\
\hline $\begin{array}{l}\text { Modified, Modified Continuity } \\
\text { Index (MMCI })^{31} \\
\text { Index of Concentration } \\
(\mathrm{CON})^{22,38} \\
\text { GINI Index of Concentration } \\
(\mathrm{GINI})^{22,38}\end{array}$ & $\begin{array}{l}\text { Gill \& Mainous, } 1998^{90} \\
\text { Gill et al, 2000115 } \\
\text { Neher et al, } 2001^{124}\end{array}$ & & $\begin{array}{l}\text { Howie et al, } 1999104 \\
\text { Kearley et al, } 2001^{62} \\
\text { Kingston, } 1983^{58} \\
\text { Kogan et al, } 1995^{133} \\
\text { Lambrew et al, } 2002^{78} \\
\text { Love et al, 200048 } \\
\text { O'Connor et al, } 1998^{103} \\
\text { O'Malley et al, } 1997^{89}\end{array}$ \\
\hline $\begin{array}{l}\text { K Index }(K)^{34,39} \\
\text { FRAC Index (FRAC) }\end{array}$ & Roos et al, $1980^{36}$ & $\begin{array}{l}\text { Measures of family } \\
\text { continuity }\end{array}$ & \\
\hline $\begin{array}{l}\text { Measures that require } \\
\text { an assigned provider }\end{array}$ & & \multirow{2}{*}{$\begin{array}{l}\text { Family Care measure (FC) }{ }^{29} \\
\text { Family Mean Continuity Index } \\
(\text { FMCl) } \\
\text { Family Continuity of Care } \\
\text { Index (FCOC) })^{37}\end{array}$} & \\
\hline $\begin{array}{l}\text { Usual Provider Continuity } \\
\text { Index (UPC) } 20,31,32,34,38,39,120\end{array}$ & 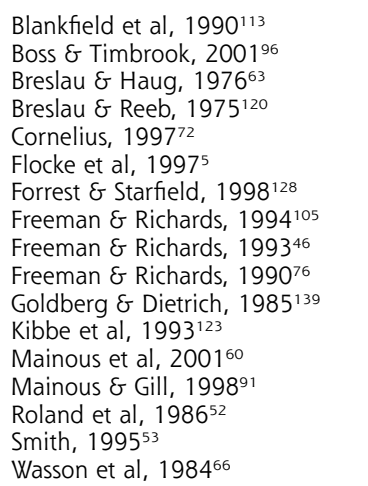 & & \\
\hline
\end{tabular}

in any of the articles in this review. In one recent study, Gill et $\mathrm{l}^{82}$ examined family continuity indirectly by comparing the quality of newborn care when babies receive care from the same provider who cared for their mothers with the quality of newborn care when babies receive care from a provider different from the provider who cared for their mothers. Family practice is the only medical specialty that provides primary care to entire family groups through the lifespan. Creative research methods will be required to show the value of this model of continuity. This literature review suggests that few of these tools exist today.

\section{DISCUSSION}

A recently published report from the Canadian Health Services Foundation has addressed the confusion regarding the definition of continuity of care. ${ }^{146}$ One 
of the conclusions of the report is that 3 types of continuity of care should be defined, informational continuity, relational continuity, and management continuity. The first 2 concepts are similar to those outlined in this article. Management continuity, however, is different and is defined as "the provision of timely and complimentary services within a shared management plan." A careful reading of the report suggests these authors might be talking about care coordination rather than continuity of care in defining this concept. But the Canadian report offers additional ideas about how to simplify and clarify a definition of continuity. The hierarchal definition defined in Table 3 has an added advantage when compared with that suggested by the Canadian report, because it focuses our attention on the relationship between these various dimensions.

This review of interpersonal continuity raises some interesting questions. Reviews done more than a decade ago called for more research to address these important questions. Is informational continuity sufficient to assure the kind of health care that patients expect and deserve, or is the personal connection inherent in interpersonal continuity an essential element? If this interpersonal intimacy is further eroded, will the essence of the healing relationship be undermined? How can information technology be used to allow interdisciplinary teams of care providers to provide the highest quality of care? Can interpersonal intimacy and trust be preserved in such a team-based model of care?

Research into continuity remains limited by differing definitions and measurement techniques. It is fine to measure patterns and concentrations of visits if we want to understand longitudinal continuity of care, but to examine accurately the outcomes related to interpersonal continuity will require actual measurement of the variable one is trying to study. Measuring these variables should not be as hard as it seems. Some investigators have simply asked patients to name their primary physicians or to characterize the length and quality of their relationships with their physicians as the independent variable in studies examining outcomes from interpersonal continuity of care. ${ }^{47,60,68,69,83,84,114}$ Another important line of inquiry could result from examining how measures of longitudinal continuity relate to the duration and quality of this relationship.

In the final analysis, family physicians should be most concerned with proving that strong, enduring physician-patient relationships improve health care. Visit patterns showing longitudinal continuity are a means to an end; they are not ends in themselves. We need to know more about how visit patterns foster strong interpersonal continuity with time. We will not have clarity of understanding about this important principal of primary care until these methodologic issues are resolved.
To read commentaries or to post a response to this article, see the online version at http://annfammed/cgi/content/full/1/3/134.

Key words: Continuity of patient care; primary health care; physicianpatient relations

Submitted August 29, 2002; submitted revised February 21, 2003, accepted March 3, 2003.

\section{References}

1. Committee on the future of primary care. Primary care: America's health in a new era. 1st ed. Washington, DC: Institute of Medicine: National Academy of Sciences; 1996

2. Saultz JW. Continuity of care. In: Saultz JW, ed. Textbook of family medicine. 1st ed. New York, NY: McGraw-Hill; 2000:52-77.

3. McWhinney IR. Principles of family medicine. In: McWhinney IR, ed. A textbook of family medicine. 2nd ed. New York, NY: Oxford University Press; 1997:18-20.

4. Kahana E, Stange KC, Meehan R, Raff L. Forced disruption in continuity of primary care: the patients' perspective. Sociol Focus 1997;30:177-187.

5. Flocke SA, Stange KC, Zyzanski SJ. The impact of insurance type and forced discontinuity on the delivery of primary care. J Fam Pract 1997;45:129-135.

6. Kikano GE, Flocke SA, Gotler RS, Stange KC. 'My insurance changed': the negative effects of forced discontinuity of care. [Review]. Fam Pract Manage 2000;7:44-45.

7. Kletke PR, Emmons DW, Gillis KD. Current trends in physicians' practice arrangements. JAMA 1996;276:555-60.

8. Shenkin BN. The independent practice association in theory and practice. JAMA 1995;273:1937-1942.

9. Hjortdahl P. Continuity of care-going out of style? Br J Gen Pract 2001;51:699-700.

10. Newbery P. Time to rethink continuity. Can Fam Phys 2000;46: 1248-1249.

11. Emanuel EJ, Dubler NN. Preserving the physician-patient relationship in the era of managed care. JAMA 1995;273:323-329.

12. Baker R. Will the future GP remain a personal doctor? $\mathrm{Br} J$ Gen Pract 1997;47:831-834.

13. Hansen MF. Continuity of care in family practice. J Fam Pract 1975; 2:439-444.

14. Wall EM. Continuity of care and family medicine: definition, determinants, and relationship to outcome. J Fam Pract 1981;13: 655-664.

15. Banahan BF, Banahan BF I. Continuity as an attitudinal contract. J Fam Pract 1981;12:767-768.

16. Freeman $G$, Hjortdahl P. What future for continuity of care in general practice? BMJ 1997;314:1870-1873.

17. Freeman G. Continuity of care in general practice. A review and critique. Fam Pract 1984;4:1192-1194.

18. Starfield B. Continuous confusion? Am J Public Health 1980;70:117119.

19. Hennen BK. Continuity of care in family practice: part I: dimensions of continuity. J Fam Pract 1975;2:371-372.

20. Eriksson EA, Mattsson L. Quantitative measurement of continuity of care. Med Care 1983;21:858-875.

21. Rogers J, Curtis P. The concept and measurement of continuity in primary care. BMJ 1980;70:122-127. 
22. Shortell SM. Continuity of medical care: conceptualization and measurement. Med Care 1976;14:377-391.

23. Sturmberg JP. Continuity of care: towards a definition based on experiences of practicing GPs. Fam Pract 2000;17:16-20.

24. McWhinney IR. Continuity of care in family practice. Part 2: Implications of continuity. J Fam Pract 1975;2:373-374.

25. Leopold N, Cooper J, Clancy C. Sustained partnership in primary care. J Fam Pract 1996;42:129-137.

26. Freeman G. Priority given by doctors to continuity of care. J R Coll Gen Pract 1985;35:423-426.

27. Moore L, Busing N. Continuity of care in the family medicine residency. Can Fam Phys 1993;39:531-534.

28. Loxterkamp D. Being there: on the place of the family physician. J Am Board Fam Pract 1991;4:354-360.

29. Murata PJ. A visit-based quantitative measure of family care. J Fam Pract 1993;36:39-44.

30. Bice TW, Boxerman SB. A quantitative measure of continuity of care. Med Care 1977;15:347-349.

31. Magill MK, Senf J. A new method for measuring continuity of care in family practice residencies. J Fam Pract 1987;24:165-168.

32. Patten RC, Friberg R. Measuring continuity of care in a family practice residency program. J Fam Pract 1980;11:67-71.

33. Pereira Gray DJ. The key to personal care. J R Coll Gen Pract 1979; 29:666-678.

34. Ejlertsson G, Berg S. Continuity-of-care measures: an analytic and empirical comparison. Med Care 1984;22:231-239.

35. Starfield BH, Simborg DW, Horn SD, Yourtee SA. Continuity and coordination in primary care: Their achievement and utility. Med Care 1976;14:625-636.

36. Roos LL, Roos NP, Gilbert P, Nicol JP. Continuity of care: does it contribute to quality of care? Med Care 1980;18:174-184.

37. Godkin MA, Rice CA. A measure of continuity of care for physicians in practice. Fam Med 1984;16:136-140.

38. Steinwachs DM. Measuring provider continuity in ambulatory care. Med Care 1979;17:551-565

39. Smedby O, Eklund G, Eriksson EA, Smedby B. Measures of continuity of care. Med Care 1986;24:511-518.

40. Given CW. Evaluation and application of continuity measures in primary care settings. J Community Health 1985;10:22-41

41. Hruby M, Pantilat SZ, Lo B. How do patients view the role of the primary care physician in inpatient care? Am J Med 2001;111:21S-25S

42. Dietrich AJ, Marton KI. Does continuous care from a physician make a difference? J Fam Pract 1982;15:929-937.

43. Bostrom J, Tisnado J, Zimmerman J, Lazar N. The impact of continuity of nursing care personnel on patient satisfaction. J Nurs Adm 1994:24:64-68.

44. Breslau N, Mortimer EAJ. Seeing the same doctor: determinants of satisfaction of specialty care for disabled children. Med Care 1981; 19:741-758.

45. Flynn SP. Continuity of care during pregnancy: The effect of provider continuity on outcome. J Fam Pract 1985;21:375-380.

46. Freeman GK, Richards SC. Is personal continuity of care compatible with free choice of doctor? Patients' views on seeing the same doctor. Br J Gen Pract 1993:43:493-497.

47. Hjortdahl $P$, Laerum E. Continuity of care in general practice: effect on patient satisfaction. BMJ 1992;304:1287-1290.

48. Love MM, Mainous AG III, Talbert JC, Hager GL. Continuity of care and the physician-patient relationship: The importance of continuity for adult patients with asthma. J Fam Pract 2000;49: 998-1004.
49. Shortell SM, Richardson WC, LoGerfo JP, et al. The relationships among dimensions of health services in two provider systems: a causal model approach. J Health Soc Behav 1977;18:139-159.

50. Weyrauch KF. Does continuity of care increase HMO patients' satisfaction with physician performance? J Am Board Fam Pract 1996;9: $31-36$

51. Breslau N. Continuity re-examined: differential impact on satisfaction with medical care for disabled and normal children. Med Care 1982; 20:347-360.

52. Roland M, Mayor V, Morris R. Factors associated with achieving continuity of care in general practice. J R Coll Gen Pract 1986;36: 102-104.

53. Smith CS. The impact of an ambulatory firm system on quality and continuity of care. Med Care 1995;33:221-226.

54. Alpert JJ, Robertson LS, Kosa J, Haggerty MC, Haggerty RJ. Delivery of health care for children: report of an experiment. Pediatrics 1976;57:917-930.

55. Becker MH, Drachman RH, Kirscht JP. A field experiment to evaluate various outcomes of continuity of physician care. Am J Public Health 1974;64:1062-1070.

56. Alpert JJ, Kosa J, Haggerty RJ, Robertson LS, Heagarty MC. Attitude and satisfactions of low-income families receiving comprehensive pediatric care. Am J Public Health 1970;60:499-506.

57. Rowley MJ, Hensley MJ, Brinsmead MW, Wlodarczyk JH. Continuity of care by a midwife team versus routine care during pregnancy and birth: a randomized trial. Med J Aust 1995;163:289-293.

58. Kingston PO. Patient ties to ambulatory care providers: the concept of provider loyalty. J Health Care Marketing 1983;3:37-34.

59. Baker R. Characteristics of practices, general practitioners, and patients related to levels of patients' satisfaction with consultations. Br J Gen Pract 1996;46:601-605.

60. Mainous AG III, Baker R, Love MM, Pereira Gray DJ, Gill JM. Continuity of care and trust in one's physician: evidence from primary care in the United States and the United Kingdom. Fam Med 2001; 33:22-27.

61. Guthrie $B, W y k e S$. Does continuity in general practice really matter? BMJ 2000;321:734-736.

62. Kearley KE, Freeman GK, Heath A. An exploration of the value of the personal doctor-patient relationship in general practice. $\mathrm{Br} J \mathrm{Gen}$ Pract 2001:51:712-718.

63. Breslau N, Haug MR. Service delivery structure and continuity of care. J Health Soc Behav 1976;17:339-352.

64. Shear CL, Gipe BT, Mattheis JK, Levy MR. Provider continuity and quality of medical care. Med Care 1983;21:1204-1210.

65. Schmittdiel J, Selby JV, Grumbach K, Quesenberry CP. Choice of a personal physician and patient satisfaction in a health maintenance organization. JAMA 1997;278:1596-1599.

66. Wasson JH, Sauvigne AE, Mogielnicki RP, et al. Continuity of outpatient medical care in elderly men: a randomized trial. JAMA 1984; 252:2413-2417.

67. Becker $\mathrm{MH}$, Drachman RH, Kirscht JP. Continuity of pediatrician: new support for an old shibboleth. J Pediatr 1974;84:599-605.

68. Overland J, Yue DK, Mira M. Continuity of care in diabetes: to whom does it matter? Diabetes Res Clin Pract 2001:52:S55-S61.

69. Love MM, Mainous AG III. Commitment to a regular physician: How long will patients wait to see their own physician for acute illness? J Fam Pract 1999;48:202-207.

70. Liaw ST, Litt J, Radford A. Patient perceptions of continuity of care: Is there a socioeconomic factor? Fam Pract 1992;9:9-14.

71. Belle Brown J, Dickie I, Brown L, Biehn J. Longterm attendance at a family practice teaching unit: qualitative study of patients' views. Can Fam Phys 1997;43:901-906. 
72. Cornelius LJ. The degree of usual provider continuity for African and Latino Americans. J Health Care Poor Underserved 1997;8:170-185.

73. Pilotto LS, McCallum J, Raymond C, McGilchrist C, Veale Bronwyn $M$. Sequential continuity of care by general practitioners: which patients change doctor? Med J Aust 1996;164:463-466.

74. Sweeney KG, Gray DP. Patients who do not receive continuity of care from their general practitioners-are they a vulnerable group? Br J Gen Pract 1995;45:133-135.

75. Sloane $P$, Eglehoff $C$. The relationship of continuity of care to age, sex, and race. J Fam Pract 1983;16:402-405.

76. Freeman GK, Richards SC. How much personal care in four group practices? BMJ 1990;301:1028-1030.

77. Miller MH. Who receives optimal medical care? J Health Soc Behav 1973; $14: 176-182$

78. Lambrew JM, DeFriese GH, Carey TS, Ricketts TC, Biddle AK. The effects of having a regular doctor on access to primary care. Med Care 1996;34:138-151.

79. Petersen LA, Brennan TA, O'Neil AC, Cook EF, Lee TH. Does housestaff discontinuity of care increase the risk for preventable adverse events? Ann Intern Med 1994;121:866-872.

80. Sytema S, Burgess P. Continuity of care and readmission in two service systems. Acta Psychiatr Scan 1999;100:212-219.

81. Susman J, Zervanos NJ, Byerly B. Continuity of care and outcome in nursing home patients transferred to a community hospital. Fam Med 1989;21:118-121.

82. Gill JM, Saldarriaga A, Mainous AG III, Unger D. Does continuity between prenatal and well-child care improve childhood immunizations? Fam Med 2002;34:274-280

83. Hjortdahl P. Continuity of care: general practitioners' knowledge about, and sense of responsibility toward their patients. Fam Pract 1992;9:3-8.

84. Weiss LJ, Bluestein J. Faithful patients: the effect of long-term physician-patient relationships on the cost and use of health care by older Americans. Am J Public Health 1996;86:1742-1747.

85. Weyrauch KF. The personal knowledge of family physicians for their patients. Fam Med 1994;26:452-455.

86. Charney E, Bynum R, Eldredge D, et al. How well do patients take oral penicillin? A collaborative study in private practice. Pediatrics 1967;40:188-195.

87. Ettlinger PR, Freeman GK. General practice compliance study: is it worth being a personal doctor? BMJ 1981;282:1192-1194

88. Phillips DM, Shear CL. Provider continuity and control of hypertension. J Fam Pract 1984;19:793-797.

89. O'Malley AS, Mandelblatt J, Gold K, Cagney KA, Kerner J. Continuity of care and the use of breast and cervical cancer screening serv ices in a multiethnic community. Arch Intern Med 1997;157:14621470.

90. Gill JM, Mainous AG III. The role of provider continuity in preventing hospitalizations. Arch Fam Med 1998;7:352-357.

91. Mainous AG III, Gill JM. The importance of continuity of care in the likelihood of future hospitalizations: is site of care equal to a predominant clinician? Am J Public Health 1998;88:1539-1541.

92. Hennelly V, Boxerman S. Continuity of medical care: its impact on physician utilization. Med Care 1979;17:1012-1018.

93. Alpert JJ. Broken appointments. Pediatrics 1964;34:132.

94. Gordis L, Markowitz M. Evaluation of the effectiveness of comprehensive and continuous pediatric care. Pediatrics 1971;48:766-776.

95. Poland M. The effects of continuity of care on the missed appointment rate in a prenatal clinic. J Obstet Gynecol Neonat Nurs 1976;5: 45-47.
96. Boss DJ, Timbrook RE. Clinical obstetric outcomes related to continuity in prenatal care. J Am Board Fam Pract 2001;14:418-423.

97. Ettner SL. The relationship between continuity of care and the health behavior of patients. Med Care 1999;37:547-555.

98. Katz S, Vignos PJ, Moskowitz RW, Thompson HM, Svec KH. Comprehensive outpatient care in rheumatoid arthritis. JAMA 1968;206: 1249-1254.

99. Gallagher TC, Geling O, Comite F. Use of multiple providers for regular care and women's receipt of hormone replacement therapy counseling. Med Care 2001;39:1086-1096

100. Sturmberg JP, Schattner P. Personal doctoring. Its impact on continuity of care as measured by the comprehensiveness of care score Aust Fam Phys 2001;30:513-518.

101. Hanninen J, Takala J, Keinanen-Kiukaanniemi S. Good continuity of care may improve quality of life in Type 2 diabetes. Diabetes Res Clin Pract 2001;51:S21-S27.

102. Tandeter HB, Vinson DC. Transient discontinuity of care. Others seeing what we have missed. J Fam Pract 1998;47:423-424.

103. O'Connor PJ, Desai J, Rush WA, Cherney LM, Solberg LI, Bishop DB. Is having a regular provider of diabetes care related to intensity of care and glycemic control? J Fam Pract 1998;47:290-297.

104. Howie JG, Hearney DJ, Maxwell M, Walker JJ, Freeman GK, Rai H. Quality at general practice consultations: cross sectional survey. BMJ 1999;319:738-743.

105. Freeman GK, Richards SC. Personal continuity and the care of patients with epilepsy in general practice. Br J Gen Pract 1994; 44:395-399.

106. Lewis C. Does comprehensive care make a difference? What is the evidence? Am J Dis Child 1971;122:469-474.

107. Gordis L. Effectiveness of comprehensive-care programs in preventing rheumatic fever. N Engl J Med 1973;289:331-335.

108. Alpert JJ, Heagarty MC, Robertson L, Kosa J, Haggerty RJ. Effective use of comprehensive pediatric care. Am J Dis Child 1968;116:529533.

109. Ettner SL. The timing of preventive services for women and children: the effect of having a usual source of care. Am J Public Health 1996;86:1748-1754.

110. Christakis DA, Mell L, Wright JA, Davis R, Connell FA. The association between greater continuity of care and timely measles-mumpsrubella vaccine. Am J Public Health 2000;90:962-965.

111. Caplan EK, Sussman MB. Rank order of important variables for patient and staff satisfaction with outpatient service. J Health Hum Behav 1966;7:133-137.

112. Hjortdahl P. Ideology and reality of continuity of care. Fam Med $1990: 22: 361-364$

113. Blankfield RP, Kelly RB, Alemagno SA, King CM. Continuity of care in a family practice residency program. Impact on physician satisfaction. J Fam Pract 1990;31:69-73.

114. Meredith LS, Sturm R, Camp P, Wells KB. Effects of cost-containment strategies within managed care on continuity of the relationship between patients with depression and their primary care providers. Med Care 2001;39:1075-1085

115. Gill JM, Mainous AG III, Nsereko M. The effect of continuity of care on emergency department use. Arch Fam Med 2000;9:333938.

116. Hjortdahl P, Borchgrevink C. Continuity of care: influence of genera practitioners' knowledge about their patients on use of resources in consultations. BMJ 1991;303:1181-1184.

117. Raddish M, Horn SD, Sharkey PD. Continuity of care: is it cost effective? Am J Managed Care 1999;5:727-734. 
118. Christakis DA, Wright JA, Koepsell TD, Emerson S, Connell FA. Is greater continuity of care associated with less emergency department utilization? Pediatrics 1999;103:738-742.

119. Heagarty MC, Robertson LS, Kosa J, Alpert JJ. Some comparative costs in comprehensive versus fragmented pediatric care. Pediatrics 1970;46:596-603.

120. Breslau N, Reeb K. Continuity of care on a university-based practice. J Med Educ 1975;50:965-969.

121. Merenstein D, D'Amico F, Devine B, et al. Longitudinal versus traditional residencies: a study of continuity of care. Fam Med 2001;33:746-750.

122. Aylett MJ. Seeing the same doctor. J R Coll Gen Pract 1976;26:47-52.

123. Kibbe DC, Bentz E, McLaughlin CP. Continuous quality improvement for continuity of care. J Fam Pract 1993;36:304-308.

124. Neher JO, Kelsberg G, Oliveira D. Improving continuity by increasing clinic frequency in a residency setting. Fam Med 2001;33:751-755.

125. Stephens GG. Clinical biographies: issues in longitudinal care. Contin Educ 1985;260-275.

126. Retchin SM, Kerr K, White M, Blish C. Continuity of care after July. J Gen Intern Med 1986;1:94-97.

127. Geyman JP. Continuity of care in family practice: part 4. J Fam Pract $1975 ; 2: 445-447$.

128. Forrest CB, Starfield B. Entry into primary care and continuity: the effects of access. Am J Public Health 1998;88:1330-1336.

129. Safran DG, Montgomery JE, Chang H, Murphy J, Rogers WH. Switching doctors: predictors of voluntary disenrollment from a primary physician's practice. J Fam Pract 2001;50:130-135.

130. Billinghurst $B$, Whitfield $M$. Why do patients change their general practitioner? A postal questionnaire study of patients in Avon. $\mathrm{Br} J$ Gen Pract 1993:43:336-338.

131. Gabel LL, Lucas JB, Westbury RC. Why do patients continue to see the same physician? Fam Pract Res J 1993;13:133-147.

132. Gandhi IG, Parle JV, Greenfield SM, Gould S. A qualitative investigation into why patients change their GPs. Fam Pract 1997;14:49-57.
133. Kogan MD, Alexander GR, Teitelbaum MA, Jack BW, Kotelchuck M, Pappas $G$. The effect of gaps in health insurance on continuity of a regular source of care among pre-school aged children in the United States. JAMA 1995;274:1429-1435.

134. McWhinney IR. Primary care: core values. Core values in a changing world. BMJ 1998;316:1807-1809.

135. Bertakis KD, Robbins JA. Continuity of care for family practice patients in a university hospital-based residency program. Fam Pract Res J 1989;8:100-106.

136. Roberge D, Beaulieu M, Haddad S, Lebeau R, Pineault R. Loyalty to the regular provider: patients' and physicians' views. Fam Pract $2001 ; 18: 53-59$

137. Weyrauch KF, Rhodes L, Psaty BM, Grubb D. The role of physicians' personal knowledge of the patient in clinical practice. J Fam Pract 1995;40:249-256

138. Hill J, Schofield PF. The duty of continuity. J R Soc Med 1998;91:61.

139. Goldberg HI, Dietrich AJ. The continuity of care provided to primary care patients: a comparison of family physicians, general internists, and medical subspecialists. Med Care 1985;23:63-73.

140. Salisbury C. How do people choose their doctor? BMJ 1989;299: 608-610.

141. Bagley B. Hospitals and the family physician. [see comments]. Am Fam Phys 1998;58:336-339.

142. Henry LA. Working with hospitalists. Fam Pract Manage 1997;4:32-34.

143. Manian FA. Whither continuity of care? N Engl J Med 1999;340: 1362-1363.

144. Michota F, Lewis T, Cash J. The hospitalist: will inpatient specialists improve care? Cleveland Clin J Med 1998;65:297-300.

145. Fleming DM. Continuity of care: a concept revisited. Eur J Gen Pract 2000;6:140-145.

146. Reid R, Haggerty J, McKendry R. Defusing the confusion: concepts and measures of continuity of health care. 2002. Ottawa, Ontario, Canadian Health Services Research Foundation. 